\title{
PENERAPAN SISTEM PERAWATAN METODE ISMO PADA TURBIN TIPE VERTICAL FRANCIS KAPASITAS 35 MW
}

\author{
Arif Rochman Fachrudin ${ }^{1}$, Fina Andika Frida Astuti ${ }^{2}$ \\ ${ }^{1,2}$ Jurusan Teknik Mesin, Politeknik Negeri Malang \\ Jl. Soekarno Hatta No 09 Malang \\ arfachrudin@gmail.com
}

\begin{abstract}
Abstrak
Metode perawatan ISMO merupakan metode perawatan yang dilakukan pada saat performa mesin sudah mulai menurun, histori dari mesin terbatas dan kurangnya informasi dengan manual book. Metode ini menggunakan acuan derajat kerumitan untuk menentukan penjadwalannya. Metode perawatan ini diterapkan pada turbin tipe vertikal Francis kapasitas $35 \mathrm{MW}$. Tujuan dari penelitian ini adalah untuk mendapatkan informasi perawatan yang berupa jadwal perawatan dan estimasi biaya perawatan dari turbin tipe vertical francis kapasitas $35 \mathrm{MW}$. Dari penelitian ini dihasilkan jadwal perawatan secara komperehensif dan besaran biaya yang dibutuhkan mulai dari kegiatan inspeksi, small repair, medium repair dan overhoule beserta besaran biaya . Dalam satu siklus, kegiatan inspeksi dilakukan sebanyak 9 kali, medium repair 6 kali dan overhoule 1 kali. Total biaya yang dibutuhkan untuk melakukan perawatan turbin tipe vertical francis dalam jangka waktu 3 tahun adalah sebesar Rp. 97.937.000,-
\end{abstract}

Kata kunci: metode ismo, perawatan, turbin francis

\begin{abstract}
The ISMO maintenance method is a maintenance method that is carried out when the machine performance has started to decline, the history of the machine is limited and there is a lack of information with the manual book. This method uses a reference degree of complexity to determine the scheduling. This maintenance method is applied to the Francis vertical type turbine with a capacity of $35 \mathrm{MW}$. The purpose of this study is to obtain maintenance information in the form of maintenance schedules and estimated maintenance costs of the francis vertical type turbine with a capacity of $35 \mathrm{MW}$. From this research, a comprehensive maintenance schedule and cost targets are produced, starting from inspection, small repair, medium repair and over-houle activities along with the amount of costs. In one cycle, inspection activities are carried out 9 times, medium repair 6 times and overhoule 1 time. The total cost required to maintain the turbine of vertical francis type for a period of 3 years is IDR 97.937.000,-
\end{abstract}

Key words: ismo method, maintenance, francis turbines

\section{PENDAHULUAN}

Perawataan merupakan kegiatan untuk memelihara atau menjaga peralatan dan mengatasi kerusakan-kerusakan untuk dapat mengembalikan keadaan semula.[1]. Berbagai macam perawatan yang diterapkan dalam merawat suatu mesin. Salah satu metode yang sering digunakan adalah metode ISMO. Perawatan ISMO adalah perawatan terencana sesuai dengan penjadwalan yang terbagi atas inspeksi, small repair, medium repair, dan overhoule[2]. Perawatan ISMO biasanya dilakukan pada saat performa mesin sudah mulai menurun, histori dari mesin terbatas dan kurangnya informasi dari manual book mesin tersebut. Perawatan ISMO diawalai dengan penentuan derajat kerumitan suatu mesin, kemudian penentuan jenis produksi, dan waktu produksi.

Untuk menjaga performa mesin agar tetap baik pada PT XYZ dan untuk mengestimasi biaya perawatan beberapa tahun kedepan, maka diterapkan perawatan metode ISMO dalam merawat komponen mesinnya. PT. XYZ merupakan perusahaan yang menghasilkan listrik dengan memanfaatkan turbin

22 Fachrudin, Arif Rochman, dkk.; Penerapan Sistem Perawatan Metode Ismo Pada Turbin Tipe Vertical Francis Kapasitas $35 \mathrm{Mw}$ 
air. Turbin air yang digunakan adalah turbin francis. Turbin francis merupakan salah satu turbin reaksi. Turbin ini dipasang antara sumber air tekanan tinggi di bagian masuk dan air bertekanan rendah di bagian keluar. Turbin francis menggunakan sudu pengarah. Sudu pengarah mengarahkan air masuk secara tangensial. Turbin francis bekerja dengan memakai proses tekanan lebih. Pada waktu air masuk ke runner sebagian energi potensial bekerja di dalam sudu pengarah diubah sebagai kecepatan air masuk. Sisa energi tinggi jatuh dimanfaatkan dalam sudu jalan, dengan adanya pipa isap memungkinkan energi tinggi jatuh bekerja di sudu jalan dengan semaksimum mungkin. Energi mekanik turbin berasal dari penjumlahan energi kinetik dan energi potensial.[3]

Turbin yang dikelilingi dengan sudu pengarah semuanya terbenam dalam air. Air yang masuk ke dalam turbin dialirkan melalui pengisian air dari atas turbin (schact) atau melalui sebuah rumah yang berbentuk spiral (rumah keong). Daya yang dihasilkan turbin diatur dengan cara mengubah posisi pembukaan sudu pengarah. Dengan demikian kapasitas air yang masuk ke dalam roda turbin bisa diperbesar atau diperkecil. Hal ini ditunjukkan pada gambar 1 .

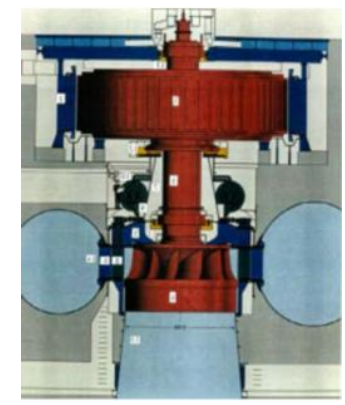

\section{Gambar 1 Turbin Francis}

\section{METODE PENELITIAN}

Metode perawatan yang digunakan adalah metode ISMO, yaitu Inspeksi, Small Repair, Medium repair dan Overhoule. Ada beberapa langkah dalam metode ISMO yaitu:

1. Identifikasi Kerusakan komponen dan langkah untuk perawatan dan perbaikan.

Identifikasi dilakukan untuk medapatkan data data kerusakan komponen untuk dilakukan perawatan dan perbaikan dan untuk mengklasifikasikan kegiatan pada kegiatan perawatan metode ISMO.

2. Menentukan derajat kerumitan.

Derajat kerumitan ditentukan dengan melihat tabel yang telah ditentukan. Setiap mesin mempunyai derajat kerumitan yang berbeda sesuai dengan klasifikasinya.

3. Menentukan siklus perawatan

Siklus perawatan ditentukan berdasarkan derajat kerumitan yang sudah didapatkan, berdasarkan tipe produksi (unit ; seri ; massal), bahan produksi (Baja carbon dan Cor ; Aluminium ; Perunggu ; Baja konstruksi) dan waktu produksi ( 1 Shift ; 2 Shift ; 3 Shift). Dari data tersebut akan dihasilkan berapa banyak kegiatan dari Inspeksi, Small Repair, Medium Repair dan Overhoule. Selain itu akan didapatkan berapa waktu masa antara 2 perawatan (Bulan) dan masa antar Overhoule (Tahun)

4. Kegiatan perawatan dan perbaikan

Kegiatan perbaikan diklasifikasikan ke dalam kegiantan I (Inspection), S (Small Repair), M (Medium Repair),dan O (Overhoule).

5. Menentukan Jadwal Perawatan Jadwal perawatan dibuat satu siklus dan berdasarkan kegiatan perawatan yang dilakukan.

6. Membuat Estimasi Biaya Perawatan

Estimasi biaya terdiri dari biaya bahan habis pakai, biaya peralatan, biaya komponen dan biaya tenaga kerja.

\section{HASIL DAN PEMBAHASAN}

\section{Identifikasi kerusakan dan tindakan}

Tabel 1 Spesifikasi Turbin tipe Vertical Francis

\begin{tabular}{ll}
\hline Output & $35 \mathrm{MW}$ \\
Head & $78 \mathrm{~m}$ \\
Discharge & $53,5 \mathrm{~m}^{3} / \mathrm{s}$ \\
Speed runner & $250 \mathrm{Rpm}$ \\
Standart specification & $\mathrm{JEC}-151(1968)$ \\
Serial No & $3600664-\mathrm{C}$ \\
Manufactured in & 1975 \\
\hline
\end{tabular}

Kerusakan kerusakan komponen yang sering terjadi adalah:

1. Guide vane

Guide vane adalah komponen yang digunakan untuk mengatur besar kecilnya aliran air yang melalui runner untuk mendapatkan beban pembangkit sesuai kebutuhan. Tindakan: Pembongkaran turbin dan penggantian guide vane. Guide van ditunjukkan pada gambar 2 . 


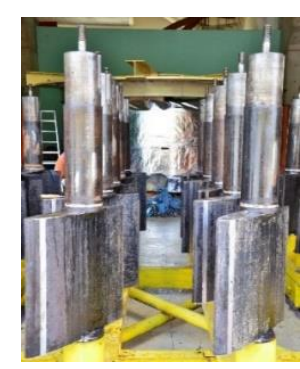

Gambar 2 Guide Van

2. Shear Pin

Shear pin merupakan komponen yang menghubungkan antara guide vane dengan servo motor agar guide vane bisa diatur seberapa bukaan yang dibutuhkan agar putaran runner stabil $250 \mathrm{Rpm}$. Kerusakan yang sering terjadi shear pin patah yang disebabkan adanya benda padat yang menabrak guide vane. Tindakan: Dilakukan pembongkaran dan penggantian shear pin. Shear pin ditunjukkan pada gambar 3.

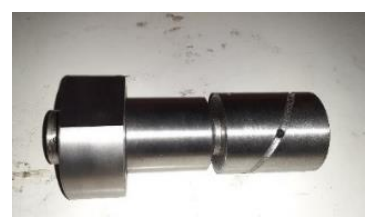

\section{Gambar 3 Shear Pin}

3. Servomotor

Servomotor sebagaimana pada gambar 4, berfungsi sebagai motor penggerak yang menggerakkan guide vane seberapa yang dibutuhkan agar putaran runner tetap stabil. Kerusakan yang terjadi seal bocor. Tindakan: melakukan penggantian seal.

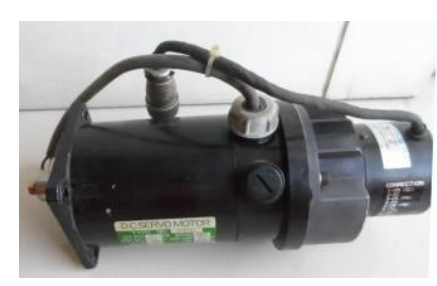

Gambar 4 Servo Motor

4. Turbin Guide Bearing

Turbin guide bearing berfungsi untuk menjaga gaya radial dari poros turbin. Turbin guide bearing ditunjukkan pada gambar 5 .

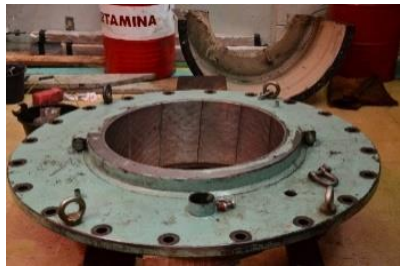

Gambar 5 Turbin Guide Bearing

Kerusakan yang terjadi adalah bearing gosong dikarenakan pelumasan tidak merata ke semua bagian turbin dan bearing aus karena kurangnya pelumasan. Tindakan: pemeriksaan ke saluran pelumasan apakah ada yang tersumbat dan pemeriksaan pada pompa lubrikasi, apakah masih berfungsi normal.

5. Runner

Runner adalah alat yang digunakan untuk mengubah energi kinetik dari air menjadi energi mekanik. Lalu, tenaga putarannya diteruskan melalui poros vertikal ke generator. Runner ditunjukkan pada gambar 6 .

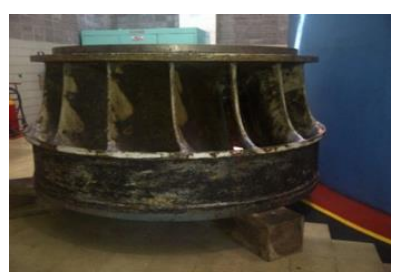

Gambar 6 Runner

Kerusakan yang terjadi adalah aus karena disebabkan adanya kavitasi. Tindakan: Membersihkan saluran admission valve agar udara bisa masuk ke ruang spiral casing

\section{Menetukan Derajat Kerumitan (Repair Complexity).}

Derajat kerumitan merupakan indikator kerumitan suatu mesin yang akan dirawat. Derajat kerumitan dibagi menjadi beberapa bagian dijelaskan di tabel 2 dibawah ini:

Tabel 2 Derajat kerumitan

\begin{tabular}{lll} 
No & Type of Production & $\begin{array}{l}\text { Average } \\
\text { Repair } \\
\text { Complexcity } \\
\text { of } \\
\end{array}$ \\
& & Equipment \\
\hline 1 & Rolling Mills (steel) & 15 \\
2 & Turbine (Steam and Hydro) & 14 \\
\hline
\end{tabular}

24 Fachrudin, Arif Rochman, dkk.; Penerapan Sistem Perawatan Metode Ismo Pada Turbin Tipe Vertical Francis Kapasitas $35 \mathrm{Mw}$ 


\begin{tabular}{|c|c|c|}
\hline No & Type of Production & $\begin{array}{l}\text { Average } \\
\text { Repair } \\
\text { Complexcity } \\
\text { of } \\
\text { Equipment }\end{array}$ \\
\hline 3 & Boiler & 12 \\
\hline 4 & $\begin{array}{l}\text { Steam Turbine for Ships } \\
\text { Aviation Engines, Heavy } \\
\text { Diesel Engines, Heavy }\end{array}$ & 11,5 \\
\hline 5 & $\begin{array}{l}\text { Machine Tools } \\
\text { Automobile, } \quad \text { Heavy }\end{array}$ & 11 \\
\hline 6 & Tractors, Ship, Aircraft & 10 \\
\hline 7 & Tractor & 9,5 \\
\hline 8 & Railway Wagon & 9 \\
\hline 9 & $\begin{array}{l}\text { Machine Tool (Medium) } \\
\text { Ball of Roller Bearing Motor }\end{array}$ & 9 \\
\hline 10 & $\begin{array}{l}\text { Cycle } \\
\text { Heavy Electrical Machines, } \\
\text { Electrical Trains, Precision }\end{array}$ & 8,5 \\
\hline 11 & $\begin{array}{l}\text { Instrument } \\
\text { Cycles Tractor Spare Parts, } \\
\text { Machine for Chemicals, } \\
\text { Industrial Paper from Wood }\end{array}$ & 8,5 \\
\hline 12 & $\begin{array}{l}\text { Pulp } \\
\text { Compressor, Hydraulic, } \\
\text { Machine, Light Machine }\end{array}$ & 8 \\
\hline 13 & Tools & 8 \\
\hline
\end{tabular}

\begin{tabular}{|c|c|c|}
\hline No & Type of Production & $\begin{array}{l}\text { Average } \\
\text { Repair } \\
\text { Complexcity } \\
\text { of } \\
\text { Equipment }\end{array}$ \\
\hline 14 & Tools and Cutters & 7,5 \\
\hline & $\begin{array}{lll}\text { Textile, } & \text { Food } & \text { Industries } \\
\text { Later, } & \text { Fire, } & \text { Protection }\end{array}$ & \\
\hline 15 & Equipment & 7,5 \\
\hline 16 & Gas Apparatus & 7 \\
\hline 17 & Low Voltage Apparatus & 7 \\
\hline 18 & Weighting Instrument & 7 \\
\hline 19 & $\begin{array}{l}\text { Electrical Instrument } \\
\text { Earth Moving Machinery }\end{array}$ & 7 \\
\hline 20 & $\begin{array}{l}\text { Showers, Buldozer ect. } \\
\text { Watches and Light }\end{array}$ & 6 \\
\hline 1 & Instrument & 5,5 \\
\hline
\end{tabular}

Dari tabel kerumitan diatas, turbin mempunyai derajat kerumitan sebesar 14. Derajat kerumitan dijadikan sebagai dasar penentuan siklus dan penentuan jumlah wahktu yang dibutuhkan dalam kegiatan perawatan.3. SIKLUS

Tabel 3 Siklus Perawatan derajat kerumitan 0 s/d 30

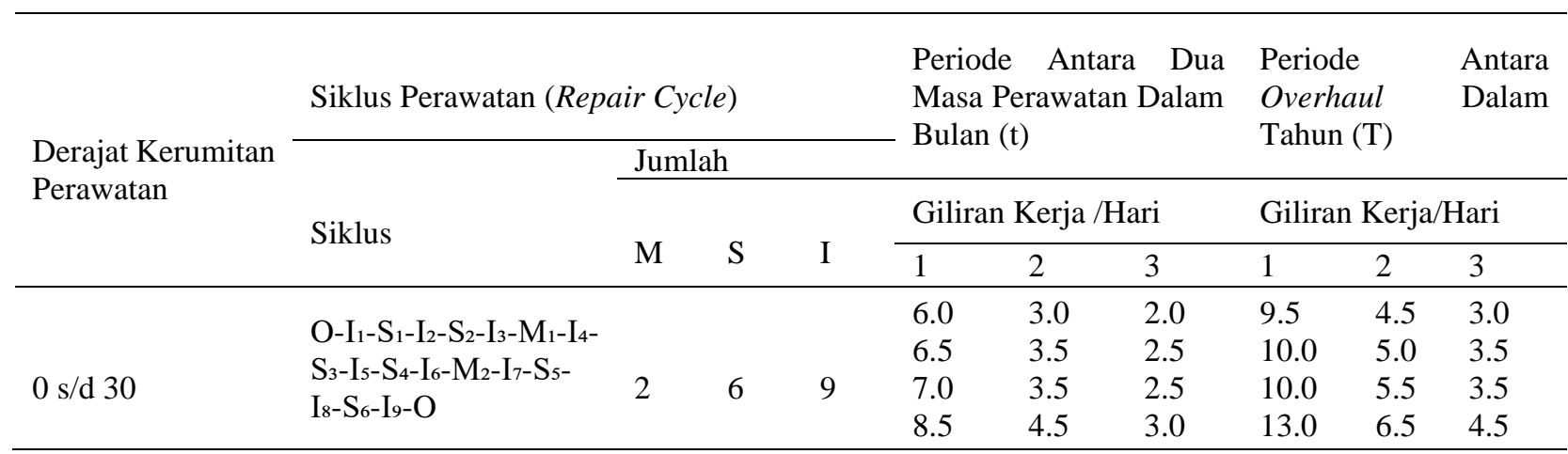

Setelah menentukan derajat kerumitan, selanjutnya menentukan siklus perawatan sesuai dengan tabel 3. Berdasarkan nilai derajat kerumitan didapat untuk turbin adalah 14 yang terletak range 0 s/d 30. Dari tabel 2 menunjukkan bahwa karena tipe produksi masal, bahan benda produksi adalah baja karbon dan cor, sifat waktu produksi 3 shift maka siklus perawatan yang dihasilkan adalah terdiri dari 9 kegiatan inspeksi, 6 kegiatan small repair, 2 kegiatan medium repair dan satu kegiatan overhoule. Periode antara 2 masa perawatan adalah 2 bulan. Periode untuk antar overhoule adalah 3 tahun. Siklus tersebut adalah : O-I ${ }_{1}-\mathrm{S}_{1}-\mathrm{I}_{2}-\mathrm{S}_{2}-\mathrm{I}_{3}-\mathrm{M}_{1}-\mathrm{I}_{4}-\mathrm{S}_{3}-\mathrm{I}_{5}-\mathrm{S}_{4}-\mathrm{I}_{6}-\mathrm{M}_{2}-\mathrm{I}_{7}-\mathrm{S}_{5}-\mathrm{I}_{8}-$ $\mathrm{S}_{6}-\mathrm{I}_{9}-\mathrm{O}$

\section{Kegiatan Pemeliharaan}

Kegiatan pemeliharaan terdiri Inspeksi,Small Repair, Medium Repair dan Overhoule.

\section{Kegiatan Inspeksi:}

a. Pemeriksaan secara visual 
b. Pemeriksaan pemakaian oli pelumas pada governoor sump tank, lubrication oil tank

c. Pembersihan bagian - bagian yang ada disekitar turbin.

d. Pembuangan oli yang tercampur dengan pelumas pada governor sump tank dan lubrication oil tank.

e. Pembersihan bagian - bagian yang ada disekitar turbin.

\section{Kegiatan Small Repair:}

a. Melakukan semua kegiatan Inspeksi.

b. Pengkalibrasian dial termo turbin bearing.

c. Pemeriksaan panel - panel control dan motor pada lubrication oil, governor sump tank, dan grase pump.

\section{Kegiatan Medium Repair:}

a. Melaksanakan semua kegiatan small Repair

b. Penggantian oli pelumas pada turbin bearing, governoor sump tank, dan lubrication oil tank.

c. Penggantian shear pin, main shaft seal, main shaft sleeve, main turbin bearing, paking draft tube dan oring P-80 for draft tube

\section{Kegiatan Overhoule:}

a. Melaksanakan semua kegiatan Medium Repair b. Penggantian turbin guide bearing

c. Penggantian runner

d. Penggantian guide vane

e. Pembersihan drafe Tube

f. Penggantian pipa- pipa sisitem pelumasan, dan sistem pendinginan pada turbin

\section{Jadwal Perawatan}

Tabel 4 merupakan jadwal perawatan pada tahun pertama. Kegiatan perawatan pada tahun pertama terdiri dari inspeksi, small repair dan medium repair. Inspeksi dilakukan pada awal bulan, bulan ke 5 dan bulan ke 9. Small repair dilakukan pada bulan ke 3 dan bulan ke 7. Medium repair dilakukan pada bulan ke 11 .

Tabel 5 menunjukkan perawatan pada tahun ke dua. Kegiatan perawatan pada tahun kedua terdiri dari inspeksi, small repair dan medium repair. Inspeksi dilakukan pada bulan ke 13, bulan ke 17 dan bulan ke 21. Small repair dilakukan pada bulan ke 15 dan bulan ke 19. Medium repair dilakukan pada bulan ke 23.

Tabel 6 menunjukkan perawatan pada tahun ke tiga. Kegiatan perawatan pada tahun ketiga terdiri dari inspeksi, small repair dan overhoule. Inspeksi dilakukan pada bulan ke 25, bulan ke 29 dan bulan ke 33. Small repair dilakukan pada bulan ke 27 dan bulan ke 31. Overhoule dilakukan pada bulan ke 35 . Overhoule merupakan puncak perawatan pada turbin francis ini.

Tabel 4 Siklus perawatan tahun pertama

\begin{tabular}{|c|c|c|c|c|c|c|c|c|c|c|c|c|}
\hline \multirow{2}{*}{ Komponen } & \multicolumn{12}{|c|}{ Bulan ke } \\
\hline & 1 & 2 & 3 & 4 & 5 & 6 & 7 & 8 & 9 & 10 & 11 & 12 \\
\hline Rumner & $T$ & & $\mathrm{~s}$ & & 1 & & $\mathrm{~s}$ & & $T$ & & M & \\
\hline Upper liner Rumner & $i$ & & s & & i & & $\mathrm{s}$ & & $i$ & & $M$ & \\
\hline Lower liner Rumner & $i$ & & s & & $\mathrm{i}$ & & s & & $i$ & & $\mathrm{M}$ & \\
\hline Top Facing Plate Rumner & $i$ & & s & & i & & s & & $i$ & & $M$ & \\
\hline Bottom Facing plate Rumner & i & & s & & i & & $\mathrm{s}$ & & $i$ & & M & \\
\hline Flush Bolt For Facing Rumner & $\mathrm{i}$ & & S & & i & & $s$ & & $i$ & & $\mathrm{M}$ & \\
\hline Guide Vane & $i$ & & s & & i & & s & & $i$ & & $M$ & \\
\hline Upper bush for guide vame & $i$ & & $\mathrm{~s}$ & & i & & $\mathrm{s}$ & & $i$ & & $\mathrm{M}$ & \\
\hline Lower bush for guide vane & $i$ & & s & & i & & s & & $i$ & & $\mathrm{M}$ & \\
\hline Shear pin & $i$ & & s & & i & & $\mathrm{s}$ & & $i$ & & $M$ & \\
\hline Main shaft geal & $i$ & & s & & i & & s & & $i$ & & M & \\
\hline Flush bolt for main shaft seal & $i$ & & s & & $\mathrm{i}$ & & s & & $i$ & & M & \\
\hline Main shaft sleeve & i & & s & & i & & $\mathrm{s}$ & & $i$ & & $M$ & \\
\hline Main Jurbin bearing & $i$ & & s & & i & & $\mathrm{s}$ & & $i$ & & M & \\
\hline Raking draft tube & $\mathrm{i}$ & & s & & $i$ & & s & & $i$ & & $\mathrm{M}$ & \\
\hline O Ring type P-80 for draft tube & $i$ & & s & & i & & s & & $i$ & & $M$ & \\
\hline Dial Thermo Meter for Iurbio Bearing & $i$ & & s & & i & & $\mathrm{s}$ & & $i$ & & $\mathrm{M}$ & \\
\hline Flush bolt for cover liner M1 $6 \times 35$ & $i$ & & s & & i & & s & & $\mathrm{i}$ & & $\mathrm{M}$ & \\
\hline Flush bolt for cover liner M1 $2 \times 30$ & $i$ & & $\mathrm{~s}$ & & $i$ & & s & & $i$ & & M & \\
\hline Flush bolt for cover liner M1 $6 \times 40$ & $i$ & & s & & i & & $\mathrm{s}$ & & $i$ & & $\mathrm{M}$ & \\
\hline Hex. HD Bolt M $30 \times 35$ and nut $\mathrm{M} 30$ & $i$ & & s & & $\mathrm{i}$ & & s & & $i$ & & $\mathrm{M}$ & \\
\hline Hex. HD Bolt M42 x 130 and nut M42 & $i$ & & s & & i & & $\mathrm{s}$ & & $i$ & & $\mathrm{M}$ & \\
\hline Hex. HD Bolt M $64 \times 140$ and nut $\mathrm{M} 64$ & $i$ & & s & & $i$ & & s & & $i$ & & $M$ & \\
\hline
\end{tabular}

Keterangan: $\mathrm{I}=$ Inspeksi, $\mathrm{S}=$ Small Repair, $\mathrm{M}=$ Medium Repair, $\mathrm{O}=$ Overhoule . 
Tabel 5 Siklus Perawatan Tahun kedua

\begin{tabular}{|c|c|c|c|c|c|c|c|c|c|c|c|c|}
\hline \multirow{2}{*}{ Komponen } & \multicolumn{12}{|c|}{ Bulan ke } \\
\hline & 1 & 2 & 3 & 4 & 5 & 6 & 7 & 8 & 9 & 10 & 11 & 12 \\
\hline Rumner & $\mathrm{I}$ & & $\mathbf{S}$ & & 1 & & $\mathbf{s}$ & & I & & M & \\
\hline Upper liner Rumner & 1 & & s & & 1 & & s & & i & & $\mathrm{M}$ & \\
\hline Lower liner Rumer & i & & s & & $i$ & & s & & $i$ & & $\mathrm{M}$ & \\
\hline Top Facing Plate Rumner & 1 & & $\mathrm{~s}$ & & 1 & & $\mathrm{~s}$ & & i & & $\mathrm{M}$ & \\
\hline Bottom Facing plate Rumner & $i$ & & s & & $i$ & & s & & i & & $M$ & \\
\hline Flush Bolt For Facing Rumner & $i$ & & s & & $i$ & & s & & $i$ & & $\mathrm{M}$ & \\
\hline Guide Vane & 1 & & $\mathrm{~s}$ & & 1 & & $\mathrm{~s}$ & & i & & $\mathrm{M}$ & \\
\hline Upper bush for guide vane & 1 & & s & & 1 & & s & & i & & $\mathrm{M}$ & \\
\hline Lower bush for guide vane & $i$ & & s & & $i$ & & s & & i & & $\mathrm{M}$ & \\
\hline Shear pin & i & & $\mathrm{s}$ & & 1 & & $s$ & & 1 & & $\mathrm{M}$ & \\
\hline Main shaft geal & 1 & & s & & 1 & & s & & i & & $M$ & \\
\hline Flush bolt for main shaft seal & $i$ & & s & & $i$ & & $\mathrm{~s}$ & & i & & $\mathrm{M}$ & \\
\hline Main shaft sleeve & i & & $\mathrm{s}$ & & $i$ & & s & & i & & $M$ & \\
\hline Main Jurbin bearing & $i$ & & s & & 1 & & s & & i & & $\mathrm{M}$ & \\
\hline Rakivg draft tube & $i$ & & $\mathrm{~s}$ & & i & & s & & $i$ & & $\mathrm{M}$ & \\
\hline O Ring type $\mathrm{P}-80$ for draft tube & 1 & & $\mathrm{~s}$ & & 1 & & $\mathrm{~s}$ & & i & & $\mathrm{M}$ & \\
\hline Dial Theroos Meter for Turbiu Bearing & 1 & & s & & i & & s & & i & & $\mathrm{M}$ & \\
\hline Flush bolt for cover liner M1 $6 \times 35$ & $i$ & & s & & $i$ & & s & & i & & $\mathrm{M}$ & \\
\hline Flush bolt for cover liner M12 $\times 30$ & $i$ & & s & & $i$ & & s & & i & & $\mathrm{M}$ & \\
\hline Flush bolt for cover liner M16 $\times 40$ & i & & s & & 1 & & s & & i & & $\mathrm{M}$ & \\
\hline Hex. HD Bolt M $30 \times 35$ and nut $\mathrm{M} 30$ & $i$ & & s & & $i$ & & $\mathrm{~s}$ & & $i$ & & $\mathrm{M}$ & \\
\hline Hex. HD Bolt M42 × 130 and nut M42 & $i$ & & s & & $i$ & & $\mathrm{~s}$ & & i & & $M$ & \\
\hline Hex. HD Bolt M $14 \times 140$ and nut M 64 & 1 & & s & & 1 & & s & & 1 & & $M$ & \\
\hline
\end{tabular}

Keterangan: $\mathrm{I}=$ Inspeksi, $\mathrm{S}=$ Small Repair, $\mathrm{M}=$ Medium Repair, $\mathrm{O}=$ Overhoule.

Tabel 6 Siklus Perawatan Tahun ketiga

\begin{tabular}{|c|c|c|c|c|c|c|c|c|c|c|c|c|}
\hline \multirow{2}{*}{ Komponen } & \multicolumn{12}{|c|}{ Bulan } \\
\hline & 25 & 26 & 27 & 28 & 29 & 30 & 31 & 32 & 33 & 34 & 35 & 36 \\
\hline Runner & 1 & & $\mathrm{~s}$ & & $\mathrm{I}$ & & $\mathrm{s}$ & & $\mathrm{I}$ & & 0 & \\
\hline Upper liner Rumner & $i$ & & $s$ & & $i$ & & $\mathrm{~s}$ & & $i$ & & 0 & \\
\hline Lower liner Rumner & $i$ & & s & & $i$ & & s & & $\mathrm{i}$ & & 0 & \\
\hline Top Facing Plate Rumner & i & & $\mathrm{s}$ & & i & & $s$ & & i & & 0 & \\
\hline Bottom Facing plate Runner & i & & $\mathrm{s}$ & & i & & 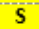 & & i & & 0 & \\
\hline Flush Bolt For Facing Rumner & $i$ & & $\mathrm{~s}$ & & $i$ & & s & & $\mathrm{i}$ & & 0 & \\
\hline Guide Vane & i & & $\mathrm{s}$ & & $i$ & & $\mathrm{~s}$ & & $i$ & & 0 & \\
\hline Upper bush for guide vane & $i$ & & 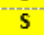 & & i & & $s$ & & $i$ & & 0 & \\
\hline Lower bush for guide vane & $i$ & & $s$ & & $i$ & & $s$ & & $\mathrm{i}$ & & 0 & \\
\hline Shear pin & i & & $\mathrm{s}$ & & i & & $s$ & & i & & 0 & \\
\hline Main shaft seal & i & & s & & $i$ & & $s$ & & $\mathrm{i}$ & & 0 & \\
\hline Flush bolt for main shaft seal & $i$ & & s & & $i$ & & $s$ & & $i$ & & 0 & \\
\hline Main shaft sleeve & i & & $\mathrm{s}$ & & i & & $s$ & & i & & 0 & \\
\hline Main Iurbin bearing & i & & $s$ & & i & & $s$ & & $i$ & & 0 & \\
\hline Raking draft tube & $i$ & & $\mathbf{s}$ & & $i$ & & $s$ & & $\mathrm{i}$ & & 0 & \\
\hline O Ring type P- 80 for draft tube & i & & $\mathrm{s}$ & & i & & $s$ & & i & & 0 & \\
\hline Dial Therno Meter for Iurbbiu Bearing & i & & $\mathrm{s}$ & & i & & $s$ & & i & & 0 & \\
\hline Flush bolt for cover liner M1 $6 \times 35$ & i & & $\mathrm{s}$ & & i & & s & & i & & 0 & \\
\hline Flush bolt for cover liner M1 $2 \times 30$ & $i$ & & $s$ & & $i$ & & $s$ & & $i$ & & 0 & \\
\hline Flush bolt for cover liner Ml $6 \times 40$ & i & & $s$ & & $i$ & & $s$ & & $\mathrm{i}$ & & 0 & \\
\hline Hex. HD Bolt M $30 \times 35$ and nut $\mathrm{M} 30$ & $i$ & & s & & i & & S & & i & & 0 & \\
\hline $\mathrm{Hex}$ HD Bolt $\mathrm{M} 42 \times 130$ and nut $\mathrm{M} 42$ & i & & $\mathrm{s}$ & & $i$ & & s & & $i$ & & 0 & \\
\hline Hex. HD Bolt M $64 \times 140$ and nut $\mathrm{M} 64$ & i & & s & & i & & s & & i & & 0 & \\
\hline
\end{tabular}

Keterangan: $\mathrm{I}=$ Inspeksi, $\mathrm{S}=$ Small Repair, $\mathrm{M}=$ Medium Repair, $\mathrm{O}=$ Overhoule .

\section{Estimasi Biaya}

Dalam estimasi biaya ada beberapa hal yang harus diketahui, yaitu berapa lama melakukan perawatan dan berapa jumlah man power yang terlibat perawatan. Menurut [4], ada tabel dalam penentuan hal tersebut berdasarkan derajat kerumitan.
Tabel 7 Waktu Perawatan

\begin{tabular}{ll}
\hline $\begin{array}{l}\text { Kategori perawatan } \\
\text { prefentif }\end{array}$ & $\begin{array}{l}\text { Jumlah hari yang diizinkan } \\
\text { per unit dari repair } \\
\text { complexity }\end{array}$ \\
\hline Inspection $(\mathrm{I})$ & 0,15 \\
\hline Small Repair $(\mathrm{S})$ & 0,25 \\
\hline Medium Repair $(\mathrm{M})$ & 0,65 \\
\hline Overhaul $(\mathrm{O})$ & 1,00 \\
\hline
\end{tabular}


Tabel 8 Jumlah Man Power

\begin{tabular}{ll}
\hline $\begin{array}{l}\text { Kategori perawatan } \\
\text { prefentif }\end{array}$ & $\begin{array}{l}\text { Jumlah orang per } \\
\text { tingkat kerumitan }\end{array}$ \\
\hline Inspection $(I)$ & 1 \\
\hline Small Repair $(S)$ & 5 \\
\hline Medium Repair $(M)$ & 18 \\
\hline Overhaul $(O)$ & 30 \\
\hline
\end{tabular}

Biaya perawatan terdiri dari biaya man power, biaya komponen dan biaya bahan habis pakai (BHP). Berikut biaya masing masing kegiatan:

\section{Biaya inspeksi adalah sebagai berikut:}

Untuk mendapatkan biaya Inspeksi harus diketahui waktu perawatan dan jumlah tenaga kerja.

- Waktu perawatan :

- = derajat kerumitan $\mathrm{x}$ hari yang diizinkan

- $=14 \times 0,15=2,1$ hari $=16,8$ jam

- Jumlah orang yang diperlukan: $8 / 16,8=0,47$ orang/jam $=1$ orang

- Biaya tenaga kerja dengan asumsi Rp. 35.000/jam

- $=$ Rp $35.000 \times 1$ orang $\times 16,8$ jam $\times 9$ kali

- $\quad=$ Rp. 5.292.000,-

- Biaya peralatan dan BHP: Majun dan sarung tangan $4 \mathrm{~kg}$ dengan harga Rp. 20.000 rupiah per $\mathrm{kg}$, sehingga $=80.000$. inspeksi sebanyak 9 kali sehingga: 9 × 80.000 rupiah $=$ Rp. 720.000

Total biaya inspeksi $:$ Rp. $5.292 .000+$ Rp. $720.000=$ Rp. 6.012.000,-

\section{Biaya Small Repair}

- Waktu perawatan: $=14 \times 0,25=3,5$ hari $=28 \mathrm{Jam}$

- Jumlah orang yang diperlukan: $=5 \times 8 / 28=1,4$ orang/jam $=2$ orang

- Biaya tenaga kerja:

$=$ Rp. $35.000 \times 2$ orang x 28 jam x 6 kali

$=$ Rp. 11.760.000,-

- Biaya peralatan dan BHP:

- Majun dan sarung tangan $4 \mathrm{~kg}$ dengan harga Rp, 20.000 per kg,sehingga $=$ Rp. 80.000 . Karena small repair ada 6 , sehingga $80.000 \times 6=\mathrm{Rp}$. 480.000

- Oli Pelumas Mobil DTE Oil Heavy Medium ISO VG 68(4 liter) x Rp. $124.000=$ Rp. 496.000

- $\quad 496.000 \times 6$ kegiatan $=$ Rp. 2.976 .000

- Total biaya BHP dan peralatan: Rp. $2.976 .000+$ Rp. $480.000=$ Rp. 3.456.000,-

Total biaya Small Repair $=$ Rp. $11.760 .000+$ Rp. $3.456 .000=$ Rp. 15.216.000,-

\section{Biaya Medium Repair}

- Waktu perawatan:
$=14 \times 0,65=9,1$ hari $=72,8 \mathrm{Jam}$

- Jumlah orang yang diperlukan:

$18 \times 8 / 72,8=2$ orang

- Biaya tenaga kerja:

$=$ Rp. $35.000 \times 2$ orang $\times 72,8$ jam $\times 2$ Kali

$=$ Rp.10.192.000,-

- Biaya peralatan dan BHP:

- Majun dan sarung tangan $4 \mathrm{~kg}$ dengan harga Rp. 20.000 per kg,sehingga= Rp. 80.000 . Karena medium repair ada 2, sehingga Rp. 80.000 × $2=$ Rp. 160.000

- Oli Pelumas Mobil DTE Oil Heavy Medium ISO VG 68(4liter) x Rp. $124.000=$ Rp. 496.000 .

Rp. 496.000 x 2 kegiatan = Rp. 992.000.

- Penggantian peralatan:

○ Penggantian shear pin, Rp. 180.000 x 2 $=$ Rp. 360.000

- main shaft seal, Rp. 320.000 x $2=$ Rp. 640.000

- main shaft sleeve, Rp. $260.000 \times 2=\mathrm{Rp}$. 520.000

- paking draft tube Rp. $30.000 \times 2=R p$. 60.000

- Oring P-80 for draft tube Rp. 8000 x 2 $=$ Rp. 16.000

Total biaya BHP dan peralatan:

Rp. $992.000+$ +Rp. $160.000+$ Rp. $360.000+$ Rp.640.000 + Rp.520.000 + Rp.60.000 + Rp. $16.000=$ Rp. 2.750 .000 .

Total biaya Medium Repair $=$ Rp.10.192.000 + Rp.2.750.000 =Rp. 12.942.000,-

\section{Biaya Overhoule}

- Waktu perawatan:

$$
=14 \times 1=14 \text { hari }=112 \mathrm{Jam}
$$

- Jumlah jam orang yang diperlukan: 8 x 30/112 $=2,1$ orang $/ \mathrm{jam}=3$ orang $/ \mathrm{jam}$

- Biaya tenaga kerja:

$=$ Rp. $35.000 \times 112 \times 3$

$=$ Rp. 11.760 .000

- Biaya peralatan dan BHP:

- Majun dan sarung tangan $8 \mathrm{~kg}$ dengan harga Rp. 20.00 per kg, sehingga $=$ Rp. 160.000 .

- Oli Pelumas Mobil DTE Oil Heavy Medium ISO VG 68 (20 liter) x Rp.124.000 = Rp. 1.240 .000

- Penggantian peralatan dan komponen:

○ Grease: $1 \mathrm{~kg} \mathrm{x} \mathrm{Rp.70.500} \mathrm{=} \mathrm{Rp.} 70.500$

- Runner 1 buah = Rp 12.000.000.

○ Upper Liner Runer 1 buah = Rp. 200.000

- Lower liner Runer 1 buah = Rp. 200.000 .

○ $\quad$ Top Facing Plate Runer $=$ Rp. 200.000.

$\circ \quad$ Bottom Facing Liner $=$ Rp. 25.000 .

28 Fachrudin, Arif Rochman, dkk.; Penerapan Sistem Perawatan Metode Ismo Pada Turbin Tipe Vertical Francis Kapasitas $35 \mathrm{Mw}$ 
○ Flush Bolt for Facing Runner $=\mathrm{Rp}$. 25.000.

- Guide Van 20 buah $=20 \times$ Rp 1.250 .000 $=$ Rp.25.000.000

○ Upper bush for guide vane 20 buah = 20xRp. $32.000=$ Rp. 640.000 .

- Lower bush for guide vane 20 buah $=20$ x Rp. $32.000=$ Rp. 640.000 .

- Shear pin 20 buah, $=20$ x Rp. 180.000 $=$ Rp. 3.600.000.

○ Main shaft seal, Rp. $320.000=$ Rp. 320.000 .

- Flush bolt for main shaft seal, 20 buah $=$ Rp. $500 \times 20=$ Rp. 100.000 .

○ Main shaft sleeve, Rp.260.000 = Rp. 260.000 .

○ Main Turbin bearing, 1 buah =Rp. 2.300.000.

○ Paking draft tube Rp.30.000 = Rp. 30.000,-

- Oring P-80 for draft tube 4 buah $=4 \mathrm{x}$ Rp. $8000=$ Rp. 32.000 .

- Dial Thermo Meter for Turbin Bearing $=$ Rp. 2.400 .000

- Flush bolt for cover liner M16x35 32 buah $=32 \times$ Rp. $5000=$ Rp. 160.000 .

- Flush bolt for cover liner M12x30 32 buah $=32 \times$ Rp. $5000=$ Rp. 160.000 .

- Hex. HD Bolt M30 x 35 and nut M30 8 buah $=8 \times$ Rp. $5000=$ Rp. 40.000 .

- Hex. HD Bolt M42 x 130 and nut M42 6 buah $=6$ x Rp. $5000=$ FRp. 30.000 .

- Hex. HD Bolt M64 x 140 and nut M64 2 buah $=2 \times$ Rp. $5000=$ Rp. 10.000 .

○ Penetran WD $40412 \mathrm{ml}=$ Rp. 71.000,-

○ Bensin 4 liter $=4$ x Rp. $11.000=\mathrm{Rp}$. 44.000.

○ Amplas 10 lembar $=10 \times$ Rp. $5000=$ Rp. 50.000.

- Pipa tembaga sistem pendingin $10 \mathrm{~m}=$ 10 x Rp. $100.000=$ Rp. 1.000 .000 .

$\circ \quad$ Pipa besi pendingin 10 meter $=10 \mathrm{x}$ Rp. $100.000=$ Rp. 1.000 .000 .
Total Biaya peralatan dan BHP : Rp. 52.007 .5

Total Biaya keseluruhan dalam satu siklus :

= Biaya Inspeksi + Biaya Small Repair + Biaya Medium Repair + Biaya Overhoule

$=$ Rp. 6.012.000 + Rp.15.216.000,- + Rp. 12.942.000,- + Rp. Rp 63.767.000,-

$=$ Rp.97.937.000,-

Jadi biaya total keseluruhan biatya peralatan selama 3 tahun adalah Rp.97.937.000.

\section{KESIMPULAN}

Berdasarkan perhitungan dan analisis Perawatan turbin francis kapsitas 35 MW dengan metode ISMO dapat disimpulkan :

1. Perawatan turbin Francis pada perusahaan XYZ mempunyai siklus 3 tahun, yang terdiri dari kegiatan Inspeksi sebanyak 9 kali, small repair sebanyak 6 kali, medium repair sebanyak 2 kali dan overhoule sebayak 1 kali.

2. Total biaya perawatan selama satu siklus adalah: 97.937.000 rupiah

\section{DAFTAR PUSTAKA}

[1] Astuti FAF, Sugiono, Choiron MA. Journal of Engineering and Management Industrial System Vol. 5 No . 1 Year 2017 Strategies of Maintenance Model for Exercise Book Manufacturing Machine on Paper Industry By Implementing Journal of Engineering and Management. 2017;5(1):1-7.

[2] GARD H. Industrial Maintenance. S Chand; 1976.

[3] Fachrudin AR, Purwono BS. Termodinamika. I. (Muqit A, ed.). NN Press; 2015.

[4] Suparlan S. Perawatan Mesin. ITB; 2001. 